Section Editor

Mitchell S.V. Elkind, MD, MS

Valerio Brunetti, MD

Michela Ada Noris Ferilli, MD

Viviana Nociti, MD, PhD

Gabriella Silvestri, MD, $\mathrm{PhD}$

Correspondence to

Dr. Brunetti:

v.burnetii@gmail.com
Teaching NeuroImages:

\section{Autosomal dominant leukodystrophy in a sporadic case}

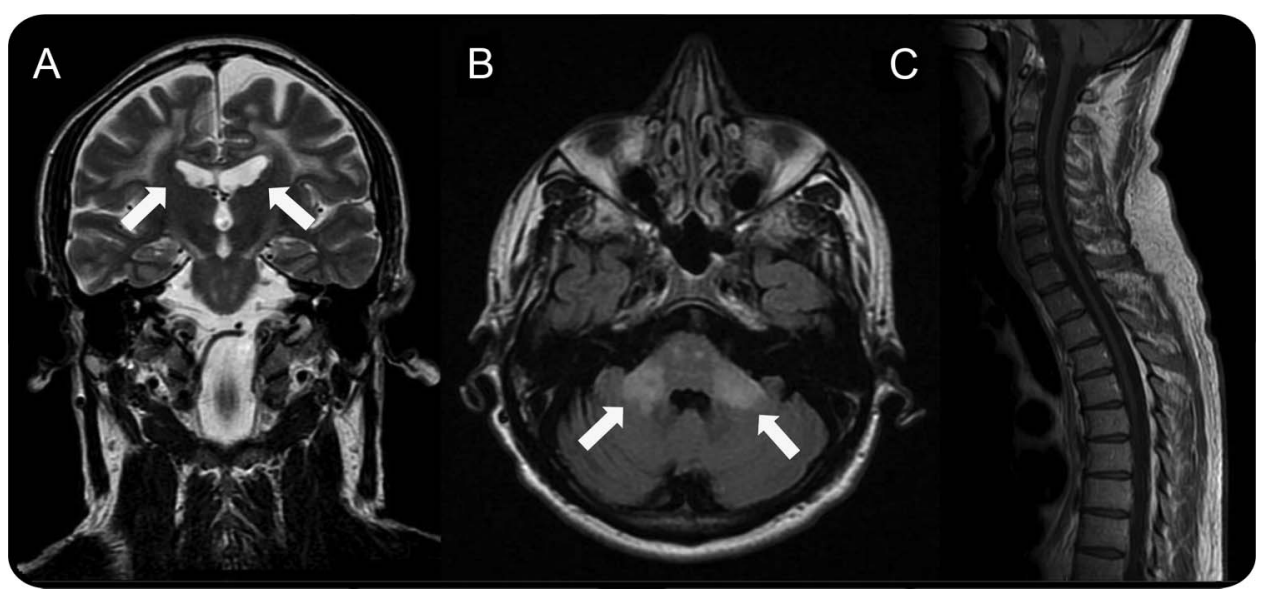

Fluid-attenuated inversion recovery sequences show symmetric hyperintense signals involving the deep white matter of both hemispheres with relative sparing of the periventricular regions ( $\mathrm{A}$, arrows) and hyperintensity of cerebellar peduncles and pontine nuclei ( $\mathrm{B}$, arrows). T1-weighted images show diffuse spinal cord atrophy (C).

A 50-year-old man with a 5-year history of progressive genitourinary dysautonomia noticed recent leg stiffness. Neurologic examination showed mild spastic paraparesis. MRI showed an unusual pattern of white matter changes in the brain and spinal cord atrophy (figure). Electroneurography, CSF, and blood/urine metabolic studies had normal results. Despite a negative family history, the patient's features were suggestive of autosomal dominant leukodystrophy (ADLD, MIM \#169500). ${ }^{1}$ Molecular testing confirmed this diagnosis, documenting a duplication in $L M N B 1$, coding for lamin $\mathrm{B} 1$. $^{2}$

ADLD is an adult-onset leukodystrophy with early presentation of dysautonomia preceding cerebellar and pyramidal signs. MRI is the best imaging technique to diagnose $\mathrm{ADLD}$.

\section{AUTHOR CONTRIBUTIONS}

Dr. Brunetti: study concept and design, drafting the manuscript, accepts responsibility for conduct of research, and acquisition of data.
Dr. Ferilli: analysis or interpretation of data, accepts responsibility for conduct of research, and acquisition of data. Dr. Nociti: analysis or interpretation of data, accepts responsibility for conduct of research. Dr. Silvestri: interpretation of data, accepts responsibility for conduct of research, study supervision, revising the manuscript, and final approval.

\section{STUDY FUNDING}

No targeted funding reported.

\section{DISCLOSURE}

The authors report no disclosures relevant to the manuscript. Go to Neurology.org for full disclosures.

\section{REFERENCES}

1. Lin ST, Ptácek LJ, Fu YH. Adult-onset autosomal dominant leukodystrophy: linking nuclear envelope to myelin. J Neurosci 2011;31:1163-1166.

2. Padiath QS, Saigoh K, Schiffmann R, et al. Lamin B1 duplications cause autosomal dominant leukodystrophy Nat Genet 2006;38:1114-1123.
Download teaching slides: Neurology.org
From the Institute of Neurology (V.B., M.A.N.F., V.N., G.S.), Department of Neurosciences, Geriatrics and Orthopedics, Catholic University of Sacred Heart, Rome; and Don Gnocchi Foundation ONLUS (V.N.), Milan, Italy. 


\section{Neurology}

\section{Teaching NeuroImages: Autosomal dominant leukodystrophy in a sporadic case}

Valerio Brunetti, Michela Ada Noris Ferilli, Viviana Nociti, et al. Neurology 2014;83; 121

DOI 10.1212/WNL.0000000000000803

This information is current as of September 15, 2014

Updated Information \&
Services
Supplementary Material
References
Subspecialty Collections
Permissions \& Licensing
Reprints

Updated Information \&

Supplementary Material

\section{References}

Subspecialty Collections

Reprints including high resolution figures, can be found at: http://n.neurology.org/content/83/12/e121.full

Supplementary material can be found at: http://n.neurology.org/content/suppl/2014/09/14/WNL.0000000000000 803.DC1

This article cites 2 articles, 1 of which you can access for free at: http://n.neurology.org/content/83/12/e121.full\#ref-list-1

This article, along with others on similar topics, appears in the following collection(s):

Autonomic diseases

http://n.neurology.org/cgi/collection/autonomic_diseases MRI

http://n.neurology.org/cgi/collection/mri

Information about reproducing this article in parts (figures,tables) or in its entirety can be found online at:

http://www.neurology.org/about/about_the_journal\#permissions

Information about ordering reprints can be found online:

http://n.neurology.org/subscribers/advertise

Neurology ${ }^{\circledR}$ is the official journal of the American Academy of Neurology. Published continuously since 1951, it is now a weekly with 48 issues per year. Copyright () 2014 American Academy of Neurology. All rights reserved. Print ISSN: 0028-3878. Online ISSN: 1526-632X.

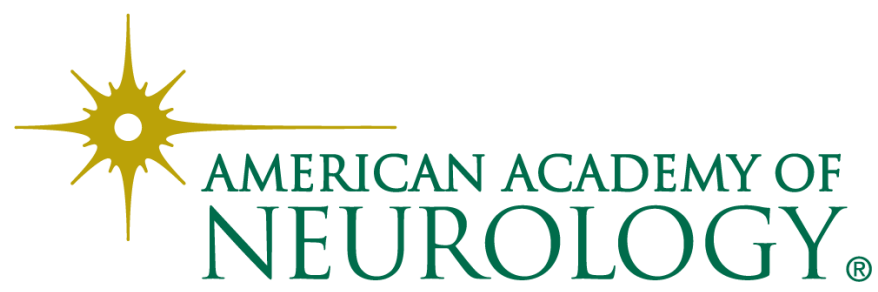

